Artikel

\title{
IMPLIKATUR PERCAKAPAN DI LAPAS WANITA KELAS II A MEDAN
}

\author{
Oleh
}

\author{
Meta Ika Gulo \\ NIM 2131210005
}

Dosen Pembimbing Skripsi

Mara Untung Ritonga, S.S., M.Hum., Ph.D

Telah Diverifikasi dan Dinyatakan Memenuhi

Syarat untuk Diunggah pada Jurnal Online

Medan, September 2017

Menyetujui :

Editor,

Dosen Pembimbing Skripsi,

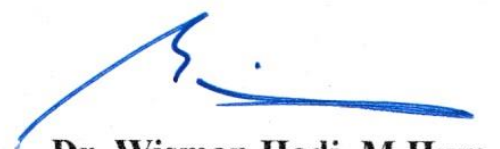

Dr. Wisman Hadi, M.Hum.

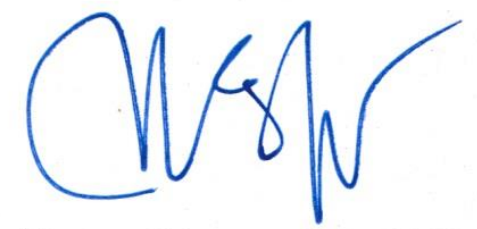

NIP 197802012003121003

Mara Untung Ritonga, S.S., M.Hum., Ph.D.

NIP 197111072006041002 


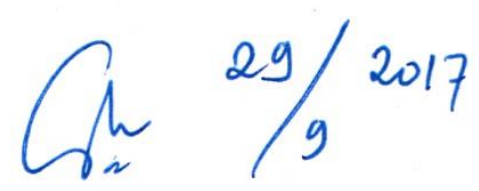

\title{
IMPLIKATUR PERCAKAPAN DI LAPAS WANITA KELAS II A MEDAN
}

\author{
Oleh \\ Meta Ika Gulo ( ikameta739@gmail.com) \\ Mara Untung Ritonga, S.S., M.Hum., Ph.D
}

Penelitian ini bertujuan untuk menganalisis jenis- jenis implikatur dan makna implikatur pada percakapan narapidana di Lapas Wanita Kelas II A Medan. Jenis penelitian yang dipakai adalah metode penelitian kualitatif deskriptif. Teknik pengumpulan data yang digunakan adalah teknik simak, wawancara, dan catat. Teknik ini digunakan agar memperoleh data secara detail dan menyeluruh. Dari hasil penelitian ditemukan 50 ujaran mengandung implikatur percakapan yang paling dominan muncul adalah implikatur percakapan khusus sebanyak 18 tuturan (36\%), selanjutnya implikatur konvensional sebanyak 15 tuturan(30\%) kemudian implikatur percakapan umum sebanyak 11 tuturan (22\%) dan terakhir implikatur berskala sebanyak 6 tuturan(12\%). Hasil penelitian implikatur percakapan di Lapas Wanita Kelas II A Medan menunjukan bahwa implikatur yang paling dominan ialah implikatur percakapan khusus hal ini berdasarkan sudut penggunaan bahasa narapidana cenderung menggunakan kata-kata khusus dan topik khusus yang hanya kalangan sesama napi yang mengerti akan makna atau maksud tuturan tersebut, sedangkan orang lain yang akan sulit untuk memahami apa yang diujarkan oleh para napi di Lapas Wanita Kelas II A Medan.

Kata Kunci : Implikatur, Makna, Lapas

\section{PENDAHULUAN}

Bahasa merupakan sarana komunikasi yang digunakan oleh penutur untuk mengungkapkan isi hati dan pikiran. Bahasa merupakan suatu alat yang paling utama untuk berkomunikasi antar manusia. Bahasa dan manusia tidak dapat dipisahkan, manusia dan bahasa memiliki sifat yang saling berkesinambungan. Manusia akan sangat tergantung pada bahasa mengingat bahwa manusia adalah makhluk sosial yang selalu berinteraksi menggunakan bahasa dalam melakukan segala aktivitasnya. Maksud tuturan dapat disampaikan dengan baik apabila 
didukung oleh situasi dan kondisi yang nyaman dan humanis. Dalam sebuah percakapan ataupun tindak tutur, penutur dan mitra tutur haruslah saling memahami dalam berkomunikasi, agar tidak menimbulkan salah pengertian. Dalam kondisi seperti inilah kajian implikatur digunakan untuk memahami makna yang tersirat yang terkandung dalam suatu tuturan.

Penelitian ini berupaya untuk mengkaji makna dan jenis implikatur percakapan yang dituturkan oleh paranapi di lapas wanita kelas II A Medan. Dalam percakapan antar sesama napi mereka cendrung membahas mengenai kasus serta pengurusan untuk remisi hukuman, sehingga tak jarang menggunakan bahasa atau pun ujaran yang sulit dimengerti atau implisit oleh orang awam atau orang lain. Untuk itu kita harus memahami konteks percakapan agar terjadi komunikasi yang baik antar sesama napi maupun pihak lain seperti petugas lapas maupun tamu di Lapas Wanita Kelas II A Medan.

Tuturan percakapan yang dilakukan di lapas khususnya dalam konteks percakapan yang dilakukan oleh pihak antar sesama tahanan terdapat makna yang tersirat yang berupa tuturan mengandung makna yang terkadang menyulitkan berbagai pihak untuk memahaminya. Makna-makna yang tersirat terkadang menimbulkan salah paham dalam memaknai maksud tuturan yang diujarkan dalam percakapan di lapas.

Penelitian yang relevan atau sejalan dengan penelitian ini adalah penelitian yang dilakukan oleh Sri Waljinah ( 2015 ) yang mengkaji implikatur dari persepsi makna simbolik bahasa hukum. Sejalan dengan itu, penelitian yang dilakukan oleh Dwi Fitriyani (2016) yang mengkaji implikatur percakapan mahasiswa STKIP Muhammadiyah Pringsewu Lampung.

Fenomena di atas mendorong penulis untuk meneliti lebih jauh tentang implikatur percakapan. Adapun judul penelitian ini adalah "Implikatur Percakapan di Lapas Wanita Kelas II A Medan”.

\section{METODE PENELITIAN}

Metode yang dipergunakan dalam penelitian ini adalah metode penelitian deskriptif kualitatif yang bersifat deskriptif analisis. Metode deskriptif merupakan 
suatu cara untuk memecahkan permasalahan yang menjadi tujuan dalam penelitian ini dengan cara mendeskripsikan dan menggambarkan keadaan subjek atau objek penelitian berdasarkan fakta-fakta yang ditemukan di lokasi penelitian. Mengenai penelitian kualitatif ini menurut Moleong (2016:6) mengatakan "penelitian kualitatif adalah penelitian yang bermaksud untuk memahami fenomena tentang apa yang dialami oleh subjek penelitian misalnya perilaku, persepsi, motivasi, tindakan dan lain sebagainya".

\section{HASIL PENELITIAN}

\section{Jenis -Jenis Implikatur}

Tuturan percakapan narapidana di Lapas Wanita Kelas II A Medan ditemukan 50 implikatur. Implikatur yang paling dominan adalah implikatur percakapan percakapan khusus, sebanyak 18 tuturan (36\%), selanjutnya implikatur konvensional sebanyak 15 tuturan (30\%), implikatur percakapan umum sebanyak 11 tuturan (22\%) dan yang terakhir implikatur percakapan berskala sebanyak 6 tuturan (12\%). Berikut adalah sampel data penelitian.

\section{a. Implikatur Percakapan Konversional}

\section{Implikatur Percakapan Umum}

Berikut adalah sample data implikatur percakapan umum

1. Konteks percakapan : Membahas mengenai hukuman kasus judi

Np 6 :'Bentarnnya paling itu.Dimana kau ketangkap?'

Np 3 :'Bentar udah 9 bulan disini'

2. Konteks percakapan : Penutur dan mitra tutur sedang membahas mengenai kondisi serta kebetahan para napi berada di dalam lapas

Np 3 : 'Cukup enaklah disini, betah pun aku. Iya.Hahahha

Np 1 : 'Yahh!!! Gak bayar uang listrik, air, makan, yaudah kau disini aja kami mau pulang'

3. Konteks percakapan : Penutur sedang membahas mengenai lamanya hukuman atas kasus yang diterima oleh para napi

Np 5 : 'Kami pun disini mahal loh ngambil kuliahnya. Ambil S1 nya mahal disini'. 


\section{Implikatur Percakapan Berskala}

Berikut adalah sampel implikatur percakapan berskala.

1. Konteks Percakapan : Penutur membahas mengenai kartu operasi lapas yang dimiliki oleh setiap napi di dalam lapas.

Np 2 : 'Semua masing- masing serba pin'.

2. Konteks percakapan : penutur membahas menggenai kasus para napi yang bolak balik masuk kedalam lapas.

Np 5 : 'Banyak yang betah disini ya kan Ema'.

3. Konteks percakapan : Penutur membicarakan mengapa mereka melakukan tindak kejahatan

Np 1: 'Kadang- kadang kalau niat itu memang gak ada, tapi pas kena kesempatan itu'.

\section{Implikatur Percakapan Khusus}

Berikut adalah sampel data implikatur percakapan khusus

1. Konteks percakapan : Penutur dan mitra tutur membicarkan mengenai penggurusan bersyarat

Np 1 : 'CB diatas satu tahun. 1.6 kita PB'.

Np 2 : 'Cuti bersama kita kalau pembebasan bersyarat'.

2. Konteks percakapan :penutur membahas mengenai kasus judi

Np 5 : 'oh mangkubumi, lawan keras jug rupanya'

3. Konteks percakapan : Penutur membahas mengenai subsider kasus trafiking

Np 1 : 'Kalau dia berurusan dengan negara dia wajib pake

Subsider. Tipikor, uang palsu, narkoba. Kalau trafiking dia pipsus sama kayak tipikor, pipsus (pidana khusus)’.

\section{b. Implikatur Konvensional}

Berikut adalah sampel data implikatur percakapan konvensional

1. Konteks percakapan : Penutur dan mitra tutur membahas mengenai siapa yang akan memulai pembicaraan

Np 1: 'Hayo kepada ketua pembicara Ely dipersilahkan dengan hormat'. 
Np 2 : 'Yang tua duluan, hahahaha. Kita menghormati yang lebih tua.hahahha'.

2. Konteks percakapan : Penutur dan mitra tutur membicarakan mengenai kartu operasi lapas

Np 3 : 'Pake pin pin itu kami loh. Kami elis disini. Belanja aja macem orang kaya'.

Np 1 : 'Elis elis, elit loh. Pake ATM'.

3. Konteks percakapan : Penutur dan mitra tutur membahas mengenai sanksi bagi napi yang bermasalah

Np 5 : 'Berantem aja kami kena marah kena 7D. Kenak kereng’'

\section{Makna Implikatur}

Makna implikatur terdapat berdasarkan penggunaan teori dan konteks percakapan. Berdasarkan hal tersebut dapat diketahui makna implikatur dalam percakapan

\section{a. Implikatur Konversional}

1. Implikatur Percakapan Umum

Berikut adalah makna implikatur percakapan dalam tuturan sesama narapidana di Lapas Wanita Kelas II A Medan

\section{1. 'Bentar udah 9 bulan disini'}

Tuturan di atas menyimpulkan bahwa satu hari saja di dalam lapas sangat membosankan dan tidak bisa bebas melakukan apapun.

2. Cukup enaklah disini, betah pun aku. Iya, Hahahha'

Dalam tuturan di atas Penutur menyampaikan kesenangan tidak membayar tagihan seperti uang air, uang makan, uang listrik bukan menyatakan kesenangan atau betah berada di dalam sel penjara di dalam lapas.

3. 'Kami pun disini mahal loh ngambil kuliahnya. Ambil S1 nya mahal disini

Tuturan diatas menyimpulkan bahwa dibutuhkan proses yang lama untuk bisa bebas dari hukuman yang mereka terima. 


\section{Implikatur Percakapan Berskala}

Berikut adalah makna implikatur percakapan dalam tuturan sesama narapidana di Lapas Wanita Kelas II A Medan.

1. 'Semua masing- masing serba pin'.

Di dalam lapas tidak boleh membawa uang kontan, hal ini juga bertujuan agar tidak terjadi kehilangan uang dan tidak terjadi gratifikasi di dalam lapas.

\section{2. 'Banyak yang betah disini ya kan Ema}

Para napi banyak yang betah berada didalam lapas dikarenakan tidak membayar uang tagihan seperti uang air, listrik dan sebagainya, juga ingin menyampaikan bahwasanya banyak napi yang tidak jera melakukan kejahatan sehingga harus kembali di tahan di dalam lapas

3. 'Kadang- kadang kalau niat itu memang gak ada, tapi pas kena kesempatan itu'.

Para napi tidak memiliki niat sebelumnya untuk melakukan kejahatan tetapi adanya kesempatan yang membuat mereka melakukan tindak kejahatan dan harus menerima hukuman atas perbuatan yang mereka.

\section{Implikatur Percakapan Khusus}

Berikut adalah makna implikatur percakapan khusus dalam tuturan sesama narapidana di Lapas Wanita Kelas II A Medan

1. 'CB diatas satu tahun. 1.6 kita PB Cuti bersama kita kalau pembebasan bersyarat'.

Makna implisit di atas memiliki makna yaitu penggurusan untuk CB (Cuti Bersama)

2. 'oh mangkubumi, lawan keras jug rupanya'

Dalam tuturan di atas penutur menyimpulkan bahwasanya mintra tuturnya sangant pandai dalam permainan judi. Hal ini terlihat dalam ujaran ' $o h$ mangkubumi, lawan keras jug rupanya'. Dimana mangkubumi memiliki makna khusus yang berarti lawan yang kuat dan tangguh dalam permainan judi. 
3. 'Kalau dia berurusan dengan negara dia wajib pake Subsider. Tipikor, uang palsu, narkoba. Kalau trafiking dia pipsus sama kayak tipikor, pipsus (pidana khusus)'.

Makna implisit tuturan di atas adalah penjelasan mengenai subsider terkait kasus trafiking.

\section{b. Implikatur Konvensional}

Berikut adalah makna implikatur percakapan dalam tuturan sesama narapidana di Lapas Wanita Kelas II A Medan

1. 'Yang tua duluan, hahahaha. Kita menghormati yang lebih tua.'

Makna implisit dalam tuturan di atas adalah yang dituakan yang selalu dihormati.

2. 'Pake pin pin itu kami loh. Kami elis disini. Belanja aja macem orang kaya'.

Makna implisit dalam tuturan di atas adalah penggunaan kartu operasi lapas sebagai ganti penggunaan uang kontan selama berada di dalam lapas.

3. 'Berantem aja kami kena marah kena 7D. Kenak kereng'.

Makna implisit dalam tuturan di atas ialah jika para napi di dalam lapas bertengkar maka mereka akan mendapat sanksi hukuman berupa hukuman 7D atau di masukan ke dalam ruang isolasi.

\section{PEMBAHASAN HASIL PENELITIAN}

\section{a. Implikatur Konversional (Percakapan)}

Grice (dalam Purba, 2006:69-80) menyatakan ada dua jenis implikatur, yaitu implikatur konvensional dan konversional. Implikatur Konversional (percakapan) terbagi atas tiga bagian yaitu implikatur percakapan umum, implikatur percakapan berskala, dan implikatur percakapan khusus.

\section{Implikatur Percakapan Umum}

Indikator implikatur percakapan umum ialah dalam menafsirkan makna implikatur pengetahuan umum, penutur dan mitra tutur memiliki pengetahuan 
yang sama (umum). Data yang termasuk dalam jenis implikatur percakapan umum adalah :

1. Konteks percakapan : Membahas mengenai hukuman kasus judi

Np 6 :'Bentarnnya paling itu.Dimana kau ketangkap?

Np 3 :'Bentar udah 9 bulan disini'

Pada tuturan di atas, mengandung makna implikatur percakapan umum. Maka, makna implikatur dalam tuturan di atas bahwasanya penutur ( $\mathrm{Np} \mathrm{6}$ ) menyimpulkan bahwa hukuman untuk kasus judi tidak lama jika dibandingkan dengan hukuman lainnya seperti narkoba, pembunuhan, kriminal dan sebagainya. Sedangkan tuturan "Bentar udah 9 bulan disini" memiliki arti bahwa mitra tutur (Np 3) tidak setuju dengan apa yang disampaikan oleh penutur (Np 6), hal ini dapat kita ketahui secara umum bahwa satu hari saja di dalam lapas sangat membosankan dan tidak bisa bebas melakukan apapun.

2. Konteks percakapan : Penutur dan mitra tutur sedang membahas mengenai kondisi serta kebetahan para napi berada di dalam lapas

Np 3 : 'Cukup enaklah disini, betah pun aku. Iya.Hahahha

Np 1 : 'Yahh!!! Gak bayar uang listrik, air, makan, yaudah kau disini aja kami mau pulang'

Pada tuturan di atas mengandung makna implisit secara umum. secara Implikatur tuturan sebenarnya ialah penutur menyampaikan kesenangan tidak membayar tagihan seperti uang air, uang makan, uang listrik bukan menyatakan kesenangan atau betah berada di dalam sel penjara di dalam lapas.

3. Konteks percakapan : Penutur sedang membahas mengenai lamanya hukuman atas kasus yang diterima oleh para napi

Np 5 : 'Kami pun disini mahal loh ngambil kuliahnya. Ambil S1 nya mahal disini’. (DPN: 132)

Pada data di atas tuturan di atas merupakan implikatur percakapan umum. Pada dasarnya penutur menyampaikan ujaran "Kami pun disini mahal loh ngambil kuliahnya. Ambil S1 nya mahal disini” bahwasanya penutur menjelaskan butuh waktu yang lama untuk bisa keluar dari dalam sel. 


\section{Implikatur Percakapan Berskala}

Indikator implikatur percakapan berskala ini didasari oleh skala nilai. Informasi tertentu selalu disampaikan dengan memilih sebuah kata yang menyatakan suatu nilai yang tidak pasti jumlahnya. Data yang termasuk dalam jenis implikatur percakapan berskala adalah:

1. Konteks Percakapan : Penutur membahas mengenai kartu operasi lapas yang dimiliki oleh setiap napi di dalam lapas.

Np 2 : 'Semua masing- masing serba pin'

Data dari ungkapan diatas mengandung implikatur skala kuantitas. Implikatur dalam ujaran "Semua masing- masing serba pin" ialah menyatakan di dalam lapas tidak boleh membawa uang kontan, hal ini juga bertujuan agar tidak terjadi kehilangan uang dan tidak terjadi gratifikasi di dalam lapas.

2. Konteks percakapan : penutur membahas menggenai kasus para napi yang bolak balik masuk kedalam lapas.

Np 5 : 'Banyak yang betah disini ya kan Ema'.

Ujaran "Banyak yang betah disini ya kan Ema" sebenarnya memiliki maksud tersembunyi. Implikatur dalam tuturan tersebut sebenarnya ingin mengatakan bahwa para napi banyak yang betah berada didalam lapas dikarenakan tidak membayar uang tagihan seperti uang air, listrik dan sebagainya, juga ingin menyampaikan bahwasanya banyak napi yang tidak jera melakukan kejahatan sehingga harus kembali di tahan di dalam lapas.

3. Konteks percakapan : Penutur membicarakan mengapa mereka melakukan tindak kejahatan

Np 1: 'Kadang- kadang kalau niat itu memang gak ada, tapi pas kena kesempatan itu'.

Tuturan "Kadang- kadang kalau niat itu memang gak ada, tapi pas kena kesempatan itu " penutur bermaksud mengatakan bahwa mereka melakukan tindak kejahatan jika ada niat dan kesempatan maka terdapat aksi ataupun tindakan. Suatu tindak kejahatan dapat terjadi jika ada niat didorong dengan adanya kesempatan untuk melakukan tindak kejahatan tersebut. 


\section{Implikatur Percakapan Khusus}

Dalam memaknai implikatur percakapan khusus ini adalah membutuhkan pengetahuan khusus. Tanpa pengetahuan khusus sulit seseorang untuk mengetahui apa yang mungkin dimaksudkan oleh si penutur. Data yang termasuk dalam jenis implikatur percakapan khusus adalah:

1. Konteks percakapan : Penutur dan mitra tutur membicarkan mengenai penggurusan bersyarat

Np 1 : 'CB diatas satu tahun. 1.6 kita PB'.

Np 2 : 'Cuti bersama kita kalau pembebasan bersyarat'

Adapun indikator percakapan khusus ialah penutur dan mitra tutur samasama memiliki pengetahuan yag sama terkait topik pembicaraan. Adapun implikasi makna dalam tuturan diatas ialah penggurusan untuk CB (Cuti Bersama) diatas satu tahun maka akan memperoleh PB ( Pembebasan Bersyarat).

2. Konteks percakapan :penutur membahas mengenai kasus judi

Np 5 : 'oh mangkubumi, lawan keras jug rupanya'

Tuturan di atas merupakan implikatur percakapan khususDalam tuturan di atas penutur menyimpulkan bahwasanya mintra tuturnya sangant pandai dalam permainan judi. Hal ini terlihat dalam ujaran 'oh mangkubumi, lawan keras jug rupanya'. Dimana mangkubumi memiliki makna khusus yang berarti lawan yang kuat dan tangguh dalam permainan judi.

3. Konteks percakapan : Penutur membahas mengenai subsider kasus trafiking

Np 1 : 'Kalau dia berurusan dengan negara dia wajib pake

Subsider. Tipikor, uang palsu, narkoba. Kalau trafiking dia pipsus sama kayak tipikor, pipsus (pidana khusus)'

Tuturan di atas merupakan implikatur percakapan khusus. Dalam tuturan di atas penutur memberikan informasi mengenai subsidi untuk kasus yang merugikan negara seperti tifikor, uang palsu, narkoba serta trafiking. Implikatur dalam tuturan di atas penutur menyampaikan bahwasanya kasus trafiking akan mendapat subsider sama halnya dengan kasus tifikor dan pidana khusus. 


\section{b. Implikatur Konvensional}

Indikator implikatur konvensional mengandung makna yang diperoleh secarang langsung dari makna kata yang didengar. Implikatur konvensional tidak tergantung pada konteks khusus untuk mendapatkan inferensi. Makna implikatur konvensional dihasilkan dari penalaran logika dan relatif tetap. Data yang termasuk dalam jenis implikatur ini adalah:

1. Konteks percakapan : Penutur dan mitra tutur membahas mengenai siapa yang akan memulai pembicaraan

Np 1: 'Hayo kepada ketua pembicara Ely dipersilahkan dengan hormat'.

Np 2 : 'Yang tua duluan, hahahaha. Kita menghormati yang lebih tua.hahahha'.

Terdapat hubungan konvensional antara"Tua" dengan "Menghormati". Implikasi tuturan di atas adalah bahwasanya yang dituakaanlah yang memulai pembicaran.

2. Konteks percakapan : Penutur dan mitra tutur membicarakan mengenai kartu operasi lapas

Np 3 : 'Pake pin pin itu kami loh. Kami elis disini. Belanja aja macem orang kaya'.

Np 1 : 'Elis elis, elit loh. Pake ATM'.

Implikasi tuturan "Pake pin pin itu kami loh. Kami elis disini. Belanja aja macem orang kaya" ialah bahwasanya di dalam lapas tidak diperbolehkan menggunakan uang, sehingga setiap melakukan transaksi yang berkaitan dengan uang sehingga mereka diberikan kartu operasi lapas dengan pin atau kode yang berbeda untuk setiap napi.

3. Konteks percakapan : Penutur dan mitra tutur membahas mengenai sanksi bagi napi yang bermasalah

Np 5 : 'Berantem aja kami kena marah kena 7D. Kenak kereng’.

Penutur menyimpulkan jika para napi didalam lapas bertengkar maka mereka akan mendapat sanksi hukuman berupa hukuman 7D atau dimasukan kedalam 
ruang isolasi. Namun bagi setiap napi yang berkelakuan baik akan dipermudah dalam proses pengurangan hukuman serta akan dipermudah dalam proses kebebasan.

\section{PENUTUP/KESIMPULAN}

1. Hasil pemerolehan data ditemukan 50 tuturan mengandung implikatur percakapan yang paling dominan adalah implikatur percakapan khusus sebanyak 36\%, implikatur konvensional sebanyak 30\%, implikatur percakapan umum sebanyak $22 \%$ dan implikatur yang paling rendah ialah implikatur berskala sebanyak $12 \%$.

2. Hasil penelitian menunjukan bahwa implikatur yang terdapat pada percakapan para napi di Lapas Wanita Kelas II A Medan pada umumnya didominasi implikatur percakapan khusus (36\%). Hal ini disebabkan karena topik pembicaran yang dituturkan merupakan topik pembicaran yang hanya para napi yang memahami maksud yang dituturkan.Sehingga dibutuhkan pengetahuan khusus serta memahami konteks mengenai topik percakapan yang dibahas dalam percakapan antar sesama napi.

3. Hasil penelitian menunjukan bahwa implikatur yang paling sedikit dituturkan dalam percakapan para napi di lapas wanita ini ialah implikatur percakapan berskala (12\%) hal ini disebabkan para napi dalam memberikan informasi jarang menggunakan sebuah kata yang menyatakan suatu nilai yang tidak pasti jumlahnya. 


\section{DAFTAR PUSTAKA}

Fitriyani, Dwi. 2016. “Implikatur Percakapan Mahasiswa STKIP Muhammadiyah pringensewu Lampung”. Tersedia online

http://ejournal.stkipmpringsewulpg.ac.id/index.php/pesona/article/view/140/ 91 ( diakses pada 03 Januari 2017)

Moleong, J.Lexi. 2013. Metode Penelitian Kualitatif . Bandung : PTRemaja Rosdakarya . Edisi Revisi

Purba, Antilan .2002. Pragmatik Bahasa Indonesia. Medan : USU Press

Waljinah, Sri. 2015. "Linguistik Forensik Interogsi : Kajian Implikatur Percakapan dari Persspektif Makna Simbolik Bahasa Hukum”. Tersedia online:

https://jurnal.uns.ac.id/prosidingprasasti/article/view/1666(Diakses pada tanggal 01 November 2016 ) 